\title{
Disentangling antecedents and performance effects of family SME innovation: A knowledge-based perspective
}

\author{
Andreas Kallmuenzer ${ }^{1}$ • Ursula Scholl-Grissemann ${ }^{1}$
}

Published online: 24 April 2017

C The Author(s) 2017. This article is an open access publication

\begin{abstract}
Understanding how family small and medium-sized enterprises (SMEs) seize opportunities for innovation and thus achieve superior performance is of substantial interest to family firm managers and academia. This paper develops a conceptual framework of antecedents that include resources internal and external to the firm in the two major dimensions of technological innovation (TI) and management innovation (MI) and their effects on financial performance. The framework is empirically tested with survey data from 152 manufacturing family SMEs in the D-A-CH countries, which comprise Germany (D), Austria (A) and Switzerland $(\mathrm{CH})$. Drawing on the knowledge-based view, the results highlight the central role of firm-external knowledge for family firm innovation, which is inherent in an industry's technological opportunities and interorganizational collaboration. Furthermore, results show that it is only through technological innovation that family firms can capitalize on innovation. Finally, management innovation is still observed to constitute a vital complement for technological innovation in that it is an enabler for innovation in products and processes. Recommendations for practice include the need for technological innovation, openness toward collaborations with external partners and receptiveness to knowledge from external sources.
\end{abstract}

Keywords Innovation $\cdot$ Family business $\cdot \mathrm{SME} \cdot \mathrm{Knowledge-based} \mathrm{view} \cdot$ Performance

Andreas Kallmuenzer

andreas.kallmuenzer@uibk.ac.at

Ursula Scholl-Grissemann

ursula.grissemann@uibk.ac.at

1 Department of Strategic Management, Marketing and Tourism, Innsbruck University School of Management, Karl-Rahner-Platz 3, 6020 Innsbruck, Austria 


\section{Introduction}

Family business research is increasingly devoting conceptual and empirical attention to the interplay of family specific resources and the innovation capacities of family SMEs (De Massis et al. 2015; Nieto et al. 2015; Filser et al. 2016; Xi et al. 2013; LealRodríguez et al. 2016), which form the majority of firms in our society (Astrachan 2003; Voordeckers et al. 2007). Prior research has shown that family firms may compete successfully in technologically rich environments and, more importantly, that the family and its knowledge are a fundamental resource for this success (Eddleston et al. 2008; Basco 2014; Diéguez-Soto et al. 2016; Llach et al. 2012). However, research to date has neglected to provide a deeper understanding of how family-specific resources "affect their propensity toward technological innovation and, more generally, their business behavior in technological innovation" (De Massis et al. 2013, p. 21).

Since firms usually pursue multiple types of innovation simultaneously, this study is not limited to observing technological innovation. Management innovation is another major factor of influence on business performance, which despite growing academic attention is still an under-researched area (Volberda et al. 2013; Kraus et al. 2012a). Contributing to family business and innovation research, this study investigates the effect of internal and external factors on a firm's innovation (Walker et al. 2015; De Massis et al. 2013). These factors encompass the extent of Knowledge Internalization (KI) as well as the industry context/external knowledge in terms of Technological Opportunities (TO) and Interorganizational Collaboration (IC), and their effect on the two dimensions of innovation: Technological Innovation (TI) and Management Innovation (MI). Additionally, this study analyzes whether the simultaneous implementation of MI and TI leads to superior business outcomes and Financial Performance (FP) in the family business context.

Consequently, this paper contributes to the existing literature because it develops and empirically tests a comprehensive framework, with a goal of revealing the effects of antecedents of innovation embedded in firms' external and internal knowledge and the resulting pathways through which family SMEs ultimately capitalize on their resources and innovation. Therefore, the key contribution of this paper is to demonstrate that family SMEs' internal and external resources only result in increased financial performance when they translate into technological innovation. Specifically, our mediation models assist in understanding the mechanisms that explain how family SMEs' resources drive financial performance. Given that firms' innovation capabilities are part of the entrepreneurial orientation (EO) concept, this study further contributes to the under-researched area of mediation effects in the field of EO (Wales et al. 2013), which is informed by input-process-output models (MacKinnon et al. 2007).

This framework is tested in the D-A-CH countries, a region consisting of Germany, Austria and Switzerland, which ranks among the top 10 most innovative countries in the world (Innovationsindikator 2015) and has thus attracted the interest of management studies (e.g., Covin et al. 2016). It is home to the Mittelstand, which became a synonym for highly-innovative and mostly family SMEs that are predominantly active in the manufacturing industry. These firms contradict prior research findings that found family firms to be rather risk-averse and conservative entities with lower commitment toward investments in R\&D and innovation (Chrisman and Patel 2012; Naldi et al. 2007). 
The primary objective of this study is to gain a profound understanding of how family SMEs succeed in exploiting their unique resources for transforming efforts for innovation into superior performance. Hence, the paper begins with defining and integrating the conceptual background of the study. In the next section, the hypotheses for specific effects among the variables within the research framework are derived. Next, in the method section, the data and research method are described and the results of the statistical analysis are presented. To conclude this paper, the findings are discussed, and the study's limitations and implications for academia and management are presented.

\section{Theory and hypotheses}

The conceptual foundations for this study are derived from existing literature at the junction of innovation (e.g., Walker et al. 2015; Fernandes et al. 2013), family business (e.g. Chirico and Salvato 2016; De Massis et al. 2015), and SME performance literature (e.g., Keh et al. 2007; Kraus et al. 2012b), to develop an understanding of how family SMEs can source, develop and ultimately benefit from innovation. Family firms are complex entities that show a peculiar entrepreneurial behavior, driven by their simultaneous family and business orientations (Zellweger et al. 2012). Family orientation comprises long-term orientation (Lumpkin and Brigham 2011) and decision-making structures that are associated with different time horizons and intentions in comparison to non-family firms. These intentions are driven by the issues of firm succession and socio-emotional aspects such as retaining the firm's control in the family, which affect the family firm's strategizing and innovation proclivity (Zellweger et al. 2012).

Various definitions for family firms exist, demanding considerably different criteria. Conceptually, family firm definitions can be categorized into the components-of-involvement approach, where the involvement of a family is sufficient to constitute a family business, and the essence approach, where family involvement is only a necessary condition, and its intention and vision to potentially sustain across generations ultimately constitutes a family firm (Chrisman et al. 2005; Habbershon and Williams 1999; Chua et al. 1999). This paper follows the essence approach and builds on contributions by Astrachan et al. (2002) and Kellermanns et al. (2012), in that it considers various degrees of family influence on the business. Specifically, two central aspects of family influence are relevant to be considered a family firm: family control over the firm and family involvement in the management of the firm. Furthermore, family firms must not surpass the EU-recommended threshold values for the average number of employees (249) during a financial year to be characterized as family SMEs (European Commission 2003).

Exploring antecedents of family-firm innovation and its performance effects, this study divides innovation into two fundamental dimensions, tangible Technological product and process Innovation (TI) and intangible Management Innovation (MI) (Walker et al. 2015). Additionally, this research incorporates one antecedent of innovation internal to the firm, Knowledge Internalization (KI), and two antecedents of innovation containing knowledge external to the firm, Technological Opportunities (TO) and Interorganizational Collaboration (IC). This framework is illustrated in Fig. 1.

The knowledge-based view (KBV) of the firm (Grant 1996a, 1996b; Teece et al. 1997 ) is the theory this paper uses as its basis. The KBV is seen as an extension of the 


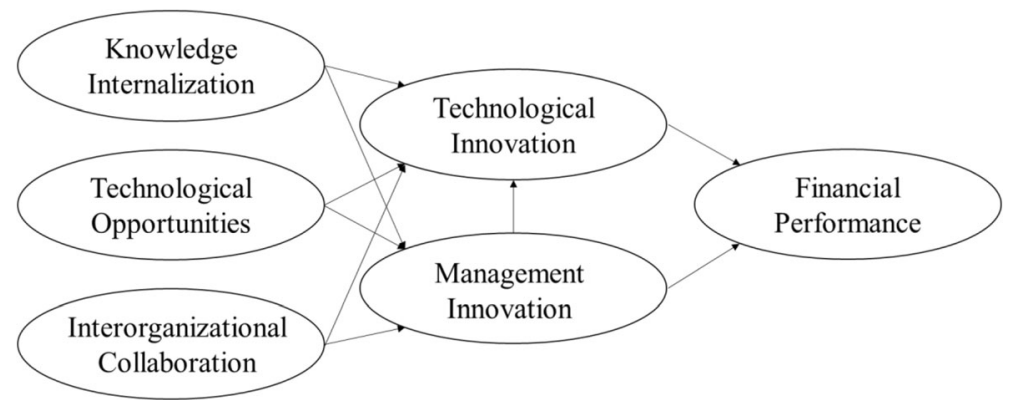

Fig. 1 Conceptual model of family SME innovation

well-established resource-based view (RBV). The RBV argues that it is not products, but firm specific resources and capabilities that are the major sources of competitive advantage for a firm, ultimately leading to superior business performance (Chirico et al. 2011; Habbershon and Williams 1999; Sirmon and Hitt 2003). This competitive advantage can only be sustained with resources that are valuable, rare, inimitable and not easily substitutable (Barney 1991). With today's rapidly changing business environments and the dissemination of IT and other technologies, knowledge can be seen as one of the most important resources for sustaining a firm's long-term competitive advantage, in addition to tangible resources or industry conditions. Therefore, knowledge is defined as the continuous process of managing all knowledge to anticipate current and future needs, to identify and exploit existing and acquired knowledge, and to develop new opportunities (Price et al. 2013). Knowledge enables the transformation and manipulation of diverse resources into novel products, processes and business practices (Alavi and Leidner 2001; Price et al. 2013).

Family businesses are socially complex entities, rich in intangible assets and pathdependent characteristics (Arregle et al. 2007), both leading to inimitability of these specific family-firm characteristics. These assets can be found in the business culture, which is based on the unique values and the reputation of the owning family. Further, the phenomenon of causal ambiguity, arising from not consciously perceived interconnections between unique family resources and the firm's sustained competitive advantage, frequently remains hidden in family firms unless systematically analyzed (Habbershon and Williams 1999). The family business patriarch's tacit knowledge is especially hard to imitate because it is subtle and not easily observable. It is not understandable by outsiders and may therefore also be characterized as a key resource leading to competitive advantages for family firms (Alavi and Leidner 2001).

Thus, the KBV considers that unique resources as argued within the RBV are necessary, but alone are not sufficient. Management, integration and deployment of resources and especially of the key resource of knowledge is seen as a critical capability within the KBV (Sirmon and Hitt 2003).

\section{Hypotheses development}

Knowledge Internalization (KI) is relevant to firm innovation (Lee et al. 2005), as knowledge and especially the capability to apply and exploit existing knowledge within a firm enables innovation. The findings show that when managers search for novel 
ideas and combine them with existing knowledge and current conditions within the firm, it ultimately results in the introduction of novel management practices (Mol and Birkinshaw 2009). Knowledge accumulation, internalization, sharing and utilization within a firm can be the source of competitive advantage and superior performance (Grant 1996b). Building on this finding, this study examines the effect of family members' KI on TI and MI and ultimately on the financial performance of the family. Considering that the intangible KI factor has been shown to influence the innovation of firms (Price et al. 2013; Zahra et al. 2007; Mol and Birkinshaw 2009) and that KI among family members forms a particular relevant internal knowledge source in family firms (Chirico and Salvato 2016), a more thorough analysis of the relationship between knowledge and innovation in family firms is worth investigating. In agreement with these findings, this study proposes that a family's collective internal knowledge (Habbershon and Williams 1999) is a key resource for TI and MI. Therefore, the following is hypothesized:

\section{Hypothesis 1: Knowledge Internalization positively affects a) Technological Inno- vation and b) Management Innovation.}

Technological Opportunities (TO) relate to the extent to which business executives identify opportunities for growth and technological change through product and process innovation in their primary industry (Klevorick et al. 1995; Zahra 1996; GarcésGaldeano et al. 2014). Two main sources of knowledge are recognized: industry sources such as suppliers, competitors or customers and non-industry sources, contributed by the academic community (Klevorick et al. 1995). While industries low in TO possess restricted opportunities for growth through commitment to R\&D and innovation activities, environments rich in TO are characterized by swiftly changing demand and customers, frequent new product introductions, dynamic market entries and exits as well as profound shifts in market shares (Eddleston et al. 2008; Zahra 1996).

TO are driven by the prevailing stock of knowledge predominant within an industry and shape opportunities for firms to build on new technologies (Eckhardt and Shane 2011). Therefore, firms established in industries with a high stock of existing external knowledge are found to have greater incentives for large R\&D investments and innovation since such an environment fosters the exploration of opportunities (VegaJurado et al. 2008). According to Eddleston et al. (2008), environments rich in TO require even greater and continuous investment in a firm's capabilities to sustain competition. The capabilities to innovate are particularly important in this context since they foster venturing activities and thus innovation (Sirmon and Hitt 2003).

Regarding family firms, Gudmundson et al. (2003) find a positive relationship between family involvement and the capability to identify and generate opportunities for innovation and to transform or renew the innovation process of the firm. This is primarily attributed to the higher likelihood of engaging in building social capital, in combination with the firms' long-term orientation (Matzler et al. 2014; Chirico and Nordqvist 2010).

In general, adapting sources of knowledge external to the firm was found to enhance a firm's technological capabilities (Becker and Peters 2000), which in turn have a positive impact on the probability of success of R\&D efforts undertaken and enhance the quality of the technologies developed. These findings are supported by further 
research in Spanish manufacturing firms that identified a positive effect of an industries' TO on innovative efforts (Nieto and Quevedo 2005) and innovation output (VegaJurado et al. 2008). Considering the separation of innovation into the two dimensions of $\mathrm{TI}$ and $\mathrm{MI}$, the following hypothesis for family firms is derived:

\section{Hypothesis 2: Technological Opportunities positively affect a) Technological Innovation and b) Management Innovation.}

Interorganizational Collaboration (IC) is assessing the degree of importance of other organizations for the various stages of the innovation process of the firm (Alexiev et al. 2016). This construct is closely related to the paradigm of open innovation (Chesbrough 2006) as "a paradigm that assumes that firms can and should use external ideas as well as internal ideas, and internal and external paths to market, as they look to advance their technology" (p. 1). Such collectivistic firm cultures as well as cooperative approaches toward external partners can contribute considerably to a successful exploitation of opportunities to sustain competition (Eddleston et al. 2008; Hollen et al. 2013; Faems et al. 2005).

However, Classen et al. (2012) found that family firms involve fewer external sources and partners in their innovation process, while a larger proportion of nonfamily members in top management positions increases the involvement of external sources for the purpose of innovation. Due to their characteristics, family firms generally tend to limit themselves by relying excessively on their existing knowledge bases while seeking new opportunities in fields too closely related to their current core businesses (Maes and Sels 2014). These two factors can restrict the family firms' access to external knowledge and capabilities, which could potentially be of importance for future business success. Nonetheless, it is through networks that SMEs gain access to resources and complementary skills, capabilities and knowledge not readily available within the rather narrow organizational boundaries of the family business (Gronum et al. 2012). Therefore, to successfully develop such novel technological innovations, IC with partners external to the firm or the establishment of a shared external facility, which is completely separated from the traditional organizational structures and boundaries, can be critical because of the context-neutrality of such new collaborative entities (Russo and Vurro 2010).

By engaging in open innovation practices, firms generally source actual innovations, technical inventions, knowledge or other useful information to support their own innovation endeavors (West and Bogers 2014). Additionally, networking with other firms to acquire new or missing knowledge and involving customers in the innovation process are prominent goals (van de Vrande et al. 2009). Finally, firms engaging in IC were found to be the most innovative, measured in terms of successful new product or process introductions (Alexiev et al. 2016).

IC is also found to have an effect on MI. Literature studying how novel management practices arise from newly established interorganizational relations (Hollen et al. 2013) argues that successful development of technological innovations within these novel forms of IC represents a major change for the participating firms. The majority of these firms and family firms in particular (Schulze et al. 2001) are traditionally focused on the internal development of product and process innovation (Russo and Vurro 2010). Thus, engagement in IC creates the need for MI because collaboration is associated with 
setting objectives, motivating employees, and coordinating activities and decision making within the innovation process and beyond the traditional organizational boundaries of the firm (Hollen et al. 2013). In summary, the following hypothesis is derived:

Hypothesis 3: Interorganizational Collaboration positively affects a) Technological Innovation and b) Management Innovation.

Regarding the research on Technological Innovation (TI), three major areas of literature can be identified, where the first two major areas study the effect of TI as output (Damanpour and Evan 1984) and the effort of technological innovation as input (Block 2012; Chrisman and Patel 2012; Jiménez-Jiménez and Sanz-Valle 2011) on financial performance. The third and smallest area argues from the RBV, and studies the effect of TI capabilities (Ortega 2010; De Massis et al. 2015) on financial performance (Camisón and Villar-López 2014). In general, the literature finds a positive relationship between TI and a firm's financial performance. Ortega (2010) finds that, especially in dynamic competitive environments, TI capabilities have a positive effect on firm performance, which supports the underlying theory of this paper that KBV is an extension of the well-established RBV. Therefore, the following is hypothesized:

\section{Hypothesis 4: Technological Innovation positively affects Financial Performance.}

In addition to the effect of TI, the isolated impact of MI on the firm's financial performance is a crucial issue in this paper. This paper follows the area of literature arguing that MI, like TI, can constitute a source of competitive advantage (Damanpour and Aravind 2012), as long as resources are valuable, rare, inimitable and not easily substitutable (Barney 1991). As such, MI can leads to superior financial performance. Although in general MI is rather tacit in nature and therefore particularly difficult to observe and to protect by patents as compared to TI, these internal business practices are still difficult to observe and difficult for competitors to imitate (Birkinshaw et al. 2008). On this basis, the following hypothesis is proposed:

\section{Hypothesis 5: Management Innovation positively affects Financial Performance.}

Mazzanti et al. (2006) find that higher engagement in organizational innovation practices positively correlates with improved firm performance. Although time and money consuming, firms usually benefit from implementing organizational innovation, although results are generally not seen sooner than three years after implementation (Armbruster et al. 2008). Walker et al. (2015) find an equality of strengths and direction concerning the impact of MI and TI on a firm's financial performance. Thus, capabilities for MI are found to be equally important as the traditional process and product innovation capabilities (Walker et al. 2015). In addition, Mol and Birkinshaw (2009) find evidence for the positive impact of the introduction of innovative management practices on productivity and thus firm performance, especially in smaller firms.

In addition, Pett and Wolff (2009) find support for the positive mediating effect of improved products and processes on SMEs' innovation-growth perspective and financial performance. Specifically, product innovation is found to enhance SME growth (Pett and Wolff 2009). Another contribution in this regard can be found in Atalay et al. 
(2013), who studied the impact of different types of innovation, including TI and MI, on the financial performance of Turkish automotive suppliers, which is seen as one of the most innovative industries in Turkey. In the existing literature, product and process innovation, specifically TI, has been proven to have a significantly positive impact on financial performance. Hence, firms are well-advised to place special emphasis on TI as it can be a major source of sustained competitive advantage (Atalay et al. 2013). Of specific interest in the context of this study is also the influence of family involvement on the TI-performance relationship. Family firms tend to invest less in innovation input (R\&D), but still tend to perform well in terms of transforming their R\&D budget into patents or innovative products (Chrisman et al. 2015; Matzler et al. 2014; Roessl et al. 2010). Based on the theoretical and empirical foundations presented, the following hypothesis is derived:

Hypothesis 6: Technological Innovation and Management Innovation mediate the effect of a) Knowledge Internalization, b) Technological Opportunities, and c) Interorganizational Collaboration on Financial Performance.

Management Innovation as an enabler for Technological Innovation. Although empirical evidence is scarce, the innovation literature further proposes that the implementation of one type of innovation adds to the value of another type of innovation (Walker et al. 2015). Existing literature indicates synergies resulting from the simultaneous pursuit of TI and MI approaches (Battisti and Stoneman 2010; Martínez-Ros and Labeaga 2009), illustrating that these two approaches serve as complements rather than substitutes for each other (Camisón and Villar-López 2014). This area of literature bases its arguments on the concept of dynamic combinative capabilities in the strategic management literature (Walker et al. 2015). In this literature, these capabilities are seen as instruments enabling the renewal of technological and non-technological capabilities and business practices within firms (Damanpour 2010). Combinative capabilities are argued to enable a firm to develop new applications for existing knowledge. Specifically, the authors refer to the capability of a firm to exploit its present knowledge with regard to some unexplored potential of existing technologies (Kogut and Zander 1992).

Extending our knowledge on the synergetic effect of TI and MI, Armbruster et al. (2008) propose that, in particular, MI can lead to TI. However, empirical evidence on this effect is scarce (Camisón and Villar-López 2014; Volberda et al. 2013). The results from general management show a positive association between administrative innovation and TI (Zahra and Covin 1994). In addition, the literature addresses the question of whether one type of innovation leads or lags behind the initiation of the other type of innovation (Damanpour and Gopalakrishnan 2001; Damanpour and Evan 1984). These studies also find that the adoption of administrative innovations tends to trigger the adoption of TI rather than the opposite, because changes in the firms' technical system require changes in the firms' social system, namely its management structure, to ensure the best possible output. Similarly, Mol and Birkinshaw (2012) argue that MI leads to TI. Further empirical support can be found in Damanpour and Gopalakrishnan (2001), arguing that new business practices such as quality control can encourage an organization to enhance efficiency and thus drive the adoption of process innovations. Based on reasoning from the RBV, research also finds that organizational innovation favors TI primarily through process innovations because "innovations in business practices, 
workplace organization or new organizational methods in external relations can favour a more efficient organization and the use of innovative manufacturing and technological processes" (Camisón and Villar-López 2014, p. 2893). In agreement with this argument, further research shows that through the implementation of MI, management must ensure that organizational structures and routines are adapted in a manner that enables technological advancement as well as the technological process innovation of a firm (Khanagha et al. 2013; Hollen et al. 2013). Since MI corresponds and significantly overlaps in terms of definition and use with the concepts of administrative, organizational or managerial innovation (Damanpour and Aravind 2012), the following hypothesis is proposed for family firms:

Hypothesis 7: Technological Innovation mediates the effect of Management Innovation on Financial Performance.

\section{Methodology}

\section{Research design}

The contact data for the online questionnaire underlying this study were collected by means of convenience sampling. The research objects of this study were family SMEs that are active in TI and MI, which can predominantly be found in the manufacturing industry (Walker et al. 2015). Therefore, family firms in the manufacturing industry in the D-A-CH region (Germany (D), Austria (A), Switzerland (CH)), a region known for its innovative Mittelstand and thus the focus of prior management research (Covin et al. 2016), were targeted. Family firms with less than 250 employees were identified through an online search of professional networks (LinkedIn and Xing) and an online firm database (Bavarian Bureau for International Business Relations). In the second step, the firms' websites were browsed for personal email contact data for CEOs or top managers. In pursuing this sampling strategy, a list of 3009 e-mail addresses for manufacturing family SMEs in high- and low-tech industries was collected. The contact e-mail message and two reminder e-mail messages resulted in a total of 242 returned questionnaires, equaling a response rate of $8.0 \%$. From these 242 questionnaires, 152 eventually qualified for the empirical analysis conducted within this study in that they were fully completed by the top management and satisfied this study's definition of a family SME. To test for non-response bias, the first $20 \%$ and the last $20 \%$ of the respondents were compared via an ANOVA, as late respondents (those only replying to reminders) are more similar to non-respondents (Armstrong and Overton 1977). No significant differences were found.

The descriptive data show that $86.2 \%$ of the surveyed family SMEs are based in Germany, 7.2\% are based in Austria and 6.6\% are based in Switzerland. Moreover, 50 of the responding firms can be characterized as micro ( $\leq 9$ employees), 62 firms as small ( $\leq 49$ employees) and 40 firms as medium-sized ( $\leq 249$ employees $)$ enterprises. The mean firm age is 45.3 years ( $\mathrm{SD}=41.1$ years). The CEOs of $91.5 \%$ of the firms are a member of the owning family. The stake of the owning family within the firm is less than $25 \%$ in 4 firms, $25-49 \%$ in 6 firms, $50-74 \%$ in 9 firms and $75-99 \%$ in 16 firms, while the majority of firms (117, equaling $77.0 \%$ ) are $100 \%$ family owned. In terms of 
family management involvement, in 69 family firms only one family member is involved in managing the family firm. In 39 family firms, two family members are engaged in managing the firm, while in the remaining 44 family firms more than two family members are involved.

\section{Measures}

The items for each construct were derived from existing scales. Knowledge Internalization measured the ability of family members to recognize, incorporate and make collective use of each other's individual knowledge (Chirico and Salvato 2016). Technological Opportunities assessed the impact of perceived technological opportunities within the firm's major industry (Eddleston et al. 2008; Zahra 1996). Interorganizational Collaboration asked the respondents to indicate the extent to which their firms pursued different forms of collaborations with other firms in the previous three years. A seven-point Likert scale ranging from 1 "not at all" to 7 "to a large extent" was used in compliance with Alexiev et al. (2016). Technological Innovation was adopted from Ngo and O'Cass (2013), and assesses the extent to which the participating firms, compared to their major competitors, utilized different approaches to technological innovation in the previous year. This construct was measured on a sevenpoint Likert scale ranging from 1 "much less than competitors" to 7 "much more than competitors". Management Innovation was adopted from Walker et al. (2015). The participants indicated their consent with three statements concerning the implementation of novel management practices within the previous three years. The scale was adapted from the original dummy coding to fit the seven-point Likert scale generally applied within the questionnaire to ensure internal consistency. Financial Performance was measured by asking respondents to assess the extent to which their firm reached its performance targets over the previous three years on a seven-point Likert scale, ranging from 1 "clearly underperformed" to 7 "clearly exceeded" (Lee 2006; Lindow et al. 2010).

To account for the variance caused by variables not directly linked to our hypotheses, we controlled for a number of firm-specific factors. Specifically, the study controlled for firm age, firm size (i.e., number of employees), stake of family ownership (i.e., percentage of the firm owned by the managing family or families) (Arregle et al. 2012), family management involvement (i.e., number of family members involved in management tasks; Hoffmann et al. 2014), revenues and generational ownership dispersion (i.e., number of generations involved in managing the firm; Kellermanns et al. 2012).

\section{Reliability and validity}

The items of the latent constructs of KI, TO, IC, TI, MI and FP were evaluated by means of a Cronbach $\alpha$, Composite Reliability (CR), Average Variance Extracted (AVE), and factor loadings from a Confirmatory Factor Analysis (CFA). Although the chi-square value for the measurement model was significant $\left(\chi^{2}=2384.55\right.$, $\mathrm{df}=276, p<.01$ ), a chi-square test alone is insufficient because it is strongly dependent on the sample size. The additional overall fit measures of our measurement model met or exceeded the recommended values ( $\mathrm{Hu}$ and Bentler 1999), as follows: $\mathrm{CFI}=.91$, $\mathrm{TLI}=.90, \mathrm{RMSEA}=.052$, and $\mathrm{SRMR}=.08$. 
One item from MI was eliminated due to a low item-to-total correlation. For the final scales, the values for Cronbach $\alpha$ and CR were above the recommended threshold of .70 , indicating satisfactory reliability of the constructs (Hair 2006; Nunnally 1978). As shown in Table 1, the average variance extracted met or exceeded the recommended minimum value of .50 (Bagozzi and Yi 1988). All factor loadings of the latent constructs were significant $(p<.01)$ and ranged from .62 to .95 , exceeding the threshold of .60 (Field 2013) and thus suggesting convergent validity. Discriminant validity was assessed by calculating the Fornell-Larcker criterion (Fornell and Larcker

Table 1 Latent construct measures

\begin{tabular}{|c|c|c|c|c|}
\hline Measures & CFA & $\alpha$ & $\mathrm{CR}$ & AVE \\
\hline Knowledge Internalization (Chirico and Salvato 2016) & & .92 & .80 & .57 \\
\hline Family members recognize potential value of peers' knowledge. & .908 & & & \\
\hline $\begin{array}{l}\text { Family members clearly understand each other's different pieces } \\
\text { of knowledge and how they fit together. }\end{array}$ & .885 & & & \\
\hline Family members efficiently use each other's unique knowledge collectively. & .915 & & & \\
\hline Technological Opportunities (Zahra 1996) & & .82 & .91 & .72 \\
\hline Opportunities for product innovation in major industry. & .875 & & & \\
\hline Opportunities for technological innovation in major industry. & .919 & & & \\
\hline Opportunities for major technological breakthroughs in major industry. & .900 & & & \\
\hline Higher R\&D spending in major industry than in most others. & .680 & & & \\
\hline Interorganizational Collaboration (Alexiev et al. 2016) & & .70 & .85 & .59 \\
\hline Collaboration with others for product innovations. & .888 & & & \\
\hline Collaboration with others to put new products to market. & .876 & & & \\
\hline Allied with others for new product introductions. & .669 & & & \\
\hline Implemented joint promotional activities for new products. & .625 & & & \\
\hline Maintained joint distribution agreements for new products. & .771 & & & \\
\hline Signed contracts with others for product development. & .880 & & & \\
\hline Technological Innovation (Ngo and O’Cass 2013) & & .84 & .85 & .66 \\
\hline Use knowledge to engage in technical innovations. & .899 & & & \\
\hline Use skills to engage in technical innovations. & .844 & & & \\
\hline Introduction of novel products or services. & .699 & & & \\
\hline Broadened service operations or technology. & .730 & & & \\
\hline Management Innovation (Walker et al. 2015) & & .70 & .72 & .57 \\
\hline New business practices. & .862 & & & \\
\hline New methods of organizing responsibility and decision-making. & .632 & & & \\
\hline \multicolumn{5}{|l|}{$\begin{array}{l}\text { New methods of organizing external relations with other organizations.* } \\
(* \text { item deleted from analysis) }\end{array}$} \\
\hline Financial Performance (Lindow et al. 2010; Lee 2006) & & .90 & .90 & .76 \\
\hline Revenue growth & .755 & & & \\
\hline Profit goal & .915 & & & \\
\hline ROS & .950 & & & \\
\hline ROI & .941 & & & \\
\hline
\end{tabular}


1981). Since the squared multiple correlations of the constructs did not exceed the AVE, discriminant validity was achieved. Table 1 shows the psychometric properties of the latent constructs. Additionally, all inter-factor correlations were below .65, suggesting that multicollinearity issues are unlikely (Tabachnick and Fidell 2012) (see Table 2). The variance inflation factor (VIF) values were all below the commonly accepted threshold of 10, further alleviating concerns about multicollinearity (Field 2013). In summary, all items and constructs used in the model showed very good reliability and validity and thus were acceptable for further analysis.

\section{Results}

\section{Direct effects}

A series of hierarchical regression analyses was conducted to test for H1-H5 (Table 3). The controls (i.e., firm age, firm size, stake of family ownership, family management involvement, revenues and general ownership dispersion) were entered into the first block (Model 1) and the predictors were entered into the second block (Model 2). The findings of the regression analyses are reported in Table 3 . TI was positively affected by KI $(\beta=.16, p<.05$, H1a supported $)$, TO ( $\beta=.46, p<.01, \mathrm{H} 2 \mathrm{a}$ supported $)$ and IC ( $\beta=.14, p<.05$, H3a supported). KI did not affect MI $(\beta=.15$, n.s., H1b not supported). MI, however, was positively affected by TO $(\beta=.17, p<.05, \mathrm{H} 2 \mathrm{~b}$ supported) and IC ( $\beta=.18, p<.05$, H3b supported). FP was positively affected by TI $(\beta=.29, p<.01, \mathrm{H} 4$ supported $)$ but not by MI ( $\beta=.08$, n.s., H5 not supported). The control variables did not significantly affect the dependent variables.

\section{Mediation analyses}

Mediation analysis helps to answer the question of how the independent variable $\mathrm{X}$ transmits its effect on the dependent variable $\mathrm{Y}$ through an intervening variable $\mathrm{M}$. Specifically, it explains the mechanism by which X influences Y (Hayes 2013). The mediation of TI and MI was tested in the relationship between $\mathrm{KI}$ (H6a), TO (H6b), and IC (H6c) on FP. The mediation was classified depending on whether the direct and indirect effects are significant. An indirect-only mediation occurs when the mediated

Table 2 Means, standard deviations and correlations of the constructs

\begin{tabular}{lllllllll}
\hline & Mean & SD & 1 & 2 & 3 & 4 & 5 & 6 \\
\hline 1. KI & 5.54 & 1.54 & 1 & & & & \\
$2 . \mathrm{TI}$ & 4.53 & 1.22 & .11 & 1 & & & \\
3. MI & 3.33 & 1.56 & .09 & $.32^{* *}$ & 1 & & & \\
4. IC & 2.89 & 1.50 & .01 & $.35^{* *}$ & $.26^{* *}$ & 1 & $.39^{* *}$ & 1 \\
5. TO & 4.03 & 1.62 & .04 & $.52^{* *}$ & $.25^{* *}$ & .15 & 1 \\
$6 . \mathrm{FP}$ & 4.49 & 1.18 & .12 & $.32^{* *}$ & .12 & .09 & .15 & \\
\hline
\end{tabular}

$* * p<.01 ; * p<.05$ 
Table 3 Results of the regression analyses

\begin{tabular}{|c|c|c|c|c|}
\hline \multicolumn{2}{|c|}{ Model } & \multicolumn{3}{|l|}{ Dependent Variables } \\
\hline & & $\begin{array}{l}\text { Technological } \\
\text { Innovation }(\mathrm{TI})\end{array}$ & $\begin{array}{l}\text { Management } \\
\text { Innovation (MI) }\end{array}$ & $\begin{array}{c}\text { Financial } \\
\text { Performance (FP) }\end{array}$ \\
\hline & Controls & $\beta$ & $\beta$ & $\beta$ \\
\hline \multirow[t]{8}{*}{1} & Firm Age & -.153 & -.161 & -.184 \\
\hline & Firm Size & .102 & .113 & .099 \\
\hline & Stake of Family Ownership & -.040 & .032 & -.002 \\
\hline & $\begin{array}{l}\text { Family Management } \\
\text { Involvement }\end{array}$ & .073 & -.038 & .062 \\
\hline & Revenues & .167 & .153 & .081 \\
\hline & $\begin{array}{l}\text { Generational Ownership } \\
\text { Dispersion }\end{array}$ & -.083 & -.019 & .032 \\
\hline & $\mathrm{R}^{2}$ & .281 & .254 & .227 \\
\hline & $F$ & 2.078 & 1.661 & 1.309 \\
\hline \multirow[t]{16}{*}{2} & Controls & & & \\
\hline & Firm Age & -.016 & -.085 & -.140 \\
\hline & Firm Size & .027 & .076 & .070 \\
\hline & Stake of Family Ownership & -.063 & .011 & .004 \\
\hline & $\begin{array}{l}\text { Family Management } \\
\text { Involvement }\end{array}$ & .018 & -.083 & .045 \\
\hline & Revenues & .254 & .202 & .033 \\
\hline & $\begin{array}{l}\text { Generational Ownership } \\
\text { Dispersion }\end{array}$ & -.091 & -.013 & .053 \\
\hline & \multicolumn{4}{|l|}{ Independent Variables } \\
\hline & $\mathrm{KI}$ & $.130 *$ & .149 & .219 \\
\hline & $\mathrm{TO}$ & $.347 *$ & $.173 *$ & .965 \\
\hline & $\mathrm{IC}$ & $.120 * *$ & $.180 * *$ & .808 \\
\hline & \multicolumn{4}{|l|}{ Mediating Variables } \\
\hline & $\mathrm{TI}$ & & & $.276^{* *}$ \\
\hline & MI & & & -.002 \\
\hline & $\mathrm{R}^{2}$ & .613 & .408 & .359 \\
\hline & $F$ & $9.478 * *$ & $3.160 *$ & $2.640 *$ \\
\hline
\end{tabular}

$* * p<.01 ; * p<.05$

effect is significant but no direct effect exists. A no-effect non-mediation, by contrast, occurs when neither the direct nor the indirect effects are significant (Zhao et al. 2010). Preacher and Hayes' (2008) bootstrapping approach was used and Hayes' (2013) Model 4 was implemented in the SPSS PROCESS macro to test for direct and indirect effects. Specifically, a parallel multiple mediator model was run, where the antecedent variable X is modeled as influencing Y through two or more mediators (Hayes 2013). Bootstrapping is a resampling strategy for estimation and hypotheses testing, where the sample represents the broader population from which the sample was derived and the calculation of the statistic of interest is generated in multiple resamples of the dataset. By using bootstrapping, no assumptions concerning the shape and distribution of the 
sample are necessary to conduct inferential tests (Preacher et al. 2007). PROCESS is a freely available macro for SPSS, which enables researchers to calculate more complex models such as multiple mediator models by providing estimates for the direct and indirect effects along with standard regression statistics. It further provides confidence intervals for the indirect effects (Hayes 2013).

Bias-corrected $95 \%$ confidence intervals were used with a bootstrap method with $\mathrm{k}=5000$ iterations for the indirect effects. Table 4 illustrates the results of the mediation analyses.

To test for H6a, KI served as the independent variable, TI and MI served as parallel mediators, and FP served as the dependent variable. The findings suggest that neither TI $\left(a \times b=.029,\left[C I_{95 \%}\right]:-0.007, .087\right)$ nor MI $(\mathrm{a} \times \mathrm{b}=-.038,[\mathrm{CI} 95 \%]:-.030,-.007)$ mediate the path of the KI on FP. The direct effect was also not significant $(c=.06$, $S E=.059, t=1.10, p=.27)$. H6a is thus not supported.

To test for H6b, TO served as the independent variable, TI and MI served as parallel mediators, and FP served as the dependent variable. The findings suggest that TI $\left(a \times b=.130,\left[C I_{95 \%}\right]: .052, .224\right)$ mediates the path of the TO on FP. MI $(a \times b=-.029$, $\left.\left[C I_{95 \%}\right]:-0.054, .031\right)$ however, did not mediate that path. H6b is thus only partially supported. The direct effect of TO on FP was not significant $(c=8.56, S E=45.46$, $t=0.19, p=.85$ ), indicating an indirect-only mediation (Zhao et al. 2010).

To test for H6c, IC served as the independent variable, TI and MI served as parallel mediators, and FP served as the dependent variable. The findings suggest that TI

Table 4 Results of the mediation analyses

\begin{tabular}{|c|c|c|c|c|c|}
\hline & & & & $95 \% B C C I$ & \\
\hline Hypothesis & Indirect Effect & Coeff. & Boot SE & Lower & Upper \\
\hline \multirow[t]{5}{*}{ H6a } & Total indirect effect & .023 & .024 & -.014 & .086 \\
\hline & $\mathrm{KI} \rightarrow \mathrm{MI} \rightarrow \mathrm{FP}$ & .029 & .023 & -.007 & .087 \\
\hline & $\mathrm{KI} \rightarrow \mathrm{MI} \rightarrow \mathrm{FP}$ & -.038 & .071 & -.030 & .007 \\
\hline & $\mathrm{R}^{2}=.143$ & & & & \\
\hline & $F(1150)=5.830$ & & & & \\
\hline \multirow[t]{5}{*}{$H 6 b$} & Total indirect effect & .121 & .047 & .034 & .223 \\
\hline & $\mathrm{TO} \rightarrow \mathrm{MI} \rightarrow \mathrm{FP}$ & .130 & .043 & .052 & .224 \\
\hline & $\mathrm{TO} \rightarrow \mathrm{MI} \rightarrow \mathrm{FP}$ & -.029 & .021 & -.054 & .031 \\
\hline & $\mathrm{R}^{2}=.022$ & & & & \\
\hline & $F(1150)=3.511$ & & & & \\
\hline \multirow[t]{5}{*}{$H 6 c$} & Total indirect effect & .083 & .040 & .006 & .166 \\
\hline & $\mathrm{IC} \rightarrow \mathrm{MI} \rightarrow \mathrm{FP}$ & .092 & .030 & .040 & .159 \\
\hline & $\mathrm{IC} \rightarrow \mathrm{MI} \rightarrow \mathrm{FP}$ & .010 & .027 & -.069 & .039 \\
\hline & $\mathrm{R}^{2}=.106$ & & & & \\
\hline & $F(1150)=5.853$ & & & & \\
\hline \multirow[t]{3}{*}{$H 7$} & $\mathrm{MI} \rightarrow \mathrm{TI} \rightarrow \mathrm{FP}$ & .108 & .034 & .048 & .183 \\
\hline & $\mathrm{R}^{2}=.105$ & & & & \\
\hline & $F(2149)=8.821$ & & & & \\
\hline
\end{tabular}


Table 5 Overview of the proposed hypotheses

\begin{tabular}{ll}
\hline Proposed Paths & Support of Hypotheses \\
\hline $\mathrm{H} 1 \mathrm{a}: \mathrm{KI} \rightarrow \mathrm{TI}$ & supported \\
$\mathrm{H} 1 \mathrm{~b}: \mathrm{KI} \rightarrow \mathrm{MI}$ & not supported \\
$\mathrm{H} 2 \mathrm{a}: \mathrm{TO} \rightarrow \mathrm{TI}$ & supported \\
$\mathrm{H} 2 \mathrm{~b}: \mathrm{TO} \rightarrow \mathrm{MI}$ & supported \\
$\mathrm{H} 3 \mathrm{a}: \mathrm{IC} \rightarrow \mathrm{TI}$ & supported \\
$\mathrm{H} 3 \mathrm{~b}: \mathrm{IC} \rightarrow \mathrm{MI}$ & supported \\
$\mathrm{H} 4: \mathrm{TI} \rightarrow \mathrm{FP}$ & supported \\
$\mathrm{H} 5: \mathrm{MI} \rightarrow \mathrm{FP}$ & not supported \\
$\mathrm{H} 6 \mathrm{a}: \mathrm{KI} \rightarrow \mathrm{TI} \rightarrow \mathrm{FP}$ & partially supported \\
$\mathrm{KI} \rightarrow \mathrm{MI} \rightarrow \mathrm{FP}$ & \\
$\mathrm{H} 6 \mathrm{~b}: \mathrm{TO} \rightarrow \mathrm{TI} \rightarrow \mathrm{FP}$ & partially supported \\
$\mathrm{TO} \rightarrow \mathrm{MI} \rightarrow \mathrm{FP}$ & \\
$\mathrm{H} 6 \mathrm{c}: \mathrm{IC} \rightarrow \mathrm{TI} \rightarrow \mathrm{FP}$ & partially supported \\
$\mathrm{IC} \rightarrow \mathrm{MI} \rightarrow \mathrm{FP}$ & \\
$\mathrm{H} 7: \mathrm{MI} \rightarrow \mathrm{TI} \rightarrow \mathrm{FP}$ & supported \\
\hline
\end{tabular}

$\left(a \times b=.092,\left[C I_{95 \%}\right]: .040, .159\right)$ mediates the path of the IC on FP, but that MI $\left(a \times b=-.010,\left[C I_{95 \%}\right]:-.069, .039\right)$ did not mediate that path. H6c is thus only partially supported. The direct effect of IC on FP was not significant $(c=-.012, S E=.069$, $t=-.175, p=.88$ ), indicating an indirect-only mediation (Zhao et al. 2010).

To test for H7, a simple mediation model was executed. MI served as the independent variable, TI served as the mediating variable, and FP served as the dependent variable. Findings suggest that TI $\left(a \times b=.108,\left[C I_{95 \%}\right]: .048, .183\right)$ mediates the effect of MI on FP, supporting H7. The direct effect was not significant $(c=-032, S E=.070$, $t=-.455, p=.69$ ), indicating an indirect-only mediation (Zhao et al. 2010). Table 5 summarizes the proposed paths of this research.

\section{Discussion and conclusions}

This study attempted to answer the question concerning the contribution of antecedents originating from sources internal and external to the firm on technological and managerial innovations in family SMEs. Additionally, this study attempted to identify the pathways of innovation on which family SMEs can ultimately capitalize. In general, the empirical insights provide broad support for the proposed research framework. KI as an antecedent showed not-significant effects on TI and MI. All other pathways of innovation with the exception of one (there is no significant effect of MI on performance) obtain empirical support. However, TI and MI were significantly affected by TO and IC. While TI significantly affected FP, no such effect was found for MI. Regarding the mediation analyses, the results show that TI mediates the effect from TO on FP and from IC on FP. MI, by contrast, did not mediate the effect of the independent variables (KI, TO, and IC) on FP. MI, however, mediates the effect of TI on FP. 
Both antecedents contributing external knowledge to the family firm gain empirical support for their effect on TI as well as MI. Specifically, empirics conducted within this study illustrate that in compliance with Nieto and Quevedo (2005) and Vega-Jurado et al. (2008), family firms operating in industries characterized by a higher level of perceived TO demonstrate higher innovativeness in their products and processes. Furthermore, they are found to be more innovative concerning their management practices. Moreover, in agreement with prior findings (Alexiev et al. 2016; van de Vrande et al. 2009), the results in this study find further evidence for the positive impact of different forms of IC on family firms' innovations in products and processes as well as innovations in management practices (Hollen et al. 2013).

Furthermore, the mediation pathways of the two antecedents external to the firm on financial performance through TI prove significance. This finding illustrates the importance of TI, since it is only through innovation of products and processes that the surveyed family SMEs can capitalize on the opportunities provided by technology and IC. This finding supports earlier contributions to the SME literature addressing the impact of TI on performance (Pett and Wolff 2009; Atalay et al. 2013).

Concerning the mediation through MI, however, in the context of family firms as compared to general management, no support for the direct impact on financial performance was found (Walker et al. 2015). However, managerial innovation sufficiently proves its reasoning as an essential contributor to the research framework of this study in two ways. First, in line with previous propositions that managerial and technological innovations serve as complements rather than substitutes (Damanpour et al. 2009; Camisón and Villar-López 2014; Walker et al. 2015), the results of the analysis show that within the surveyed family SMEs, simultaneous engagement in MI increases the positive effect of TI on financial performance. Second, the results provide confirming evidence (e.g., Damanpour and Gopalakrishnan 2001; Khanagha et al. 2013; Mol and Birkinshaw 2012) that in family firms novel management practices can also serve as enablers for product and process innovations. This occurs in such a way that MI provides an organizational structure, which fosters collaboration for new product development or a change toward more suitable organizational practices to support TI.

\section{Practical implications}

The primary goal of this study was to gain a profound understanding of how family SMEs succeed in sourcing innovations by exploiting their unique internal as well as external resources for transforming knowledge and efforts for innovation into valuable output and superior performance. Consequently, the following implications arise for a management audience from this research. If family business management succeeds in more consciously capitalizing on their unique knowledge resources, their toolkit for innovation and firm performance might well prove superior in the future. To summarize, more openness toward collaborations with external partners and general receptiveness for knowledge from external sources (Molina-Morales et al. 2014) could be rewarding. Open-mindedness to novel managerial practices and techniques, e.g., within collaborations (Bouncken et al. 2015), while at the same time retaining a majority ownership and family control (Berrone et al. 2012), might decisively strengthen the competitive position of family SMEs. 


\section{Limitations and future research}

This study is not without limitations. Since this study investigates SMEs, financial data are usually not published, and thus the data collected on financial performance relies on self-reporting. Nevertheless, research suggests that self-reported data correlates with actual objective performance (Brush and Vanderwerf 1992). Furthermore, the study built on data from SMEs with online profiles on XING and LinkedIn. This approach excludes SMEs who refrain from participating in online networks. Future studies could gather data from more complete databases offered by, for example, chambers of commerce. Another issue of this study is related to time; different types of innovations require different timeframes before their impacts are realized. In this respect, IT generates its impact on firm performance in the first years after introduction, while MI might require several years to show its effect on firm performance (Armbruster et al. 2008). It might be that MI in the surveyed family SMEs is not yet fully implemented and therefore may still develop its potential in the future. Therefore, a fruitful proposal for future research would be to study and track the development and implementation process as well as the final impact of MI within family SMEs over a longer period of time and at several stages within this process. This would contribute to an advanced understanding of the mechanisms and the potential inherent in MI.

Acknowledgements Open access funding provided by University of Innsbruck and Medical University of Innsbruck. The authors would like to sincerely thank Florian Ascherl for his valuable contribution to this research project.

Open Access This article is distributed under the terms of the Creative Commons Attribution 4.0 International License (http://creativecommons.org/licenses/by/4.0/), which permits unrestricted use, distribution, and reproduction in any medium, provided you give appropriate credit to the original author(s) and the source, provide a link to the Creative Commons license, and indicate if changes were made.

\section{References}

Alavi, M., \& Leidner, D. E. (2001). Review: Knowledge management and knowledge management systems: Conceptual foundations and research issues. MIS Quarterly, 25, 107. doi:10.2307/3250961 .

Alexiev, A. S., Volberda, H. W., \& van den Bosch, F. A. J. (2016). Interorganizational collaboration and firm innovativeness: Unpacking the role of the organizational environment. Journal of Business Research, 69 , 974-984. doi:10.1016/j.jbusres.2015.09.002 .

Armbruster, H., Bikfalvi, A., Kinkel, S., \& Lay, G. (2008). Organizational innovation: The challenge of measuring non-technical innovation in large-scale surveys. Technovation, 28, 644-657. doi:10.1016/j. technovation.2008.03.003 .

Armstrong, J. S., \& Overton, T. S. (1977). Estimating nonresponse bias in mail surveys. Journal of Marketing Research, 14, 396-402. doi:10.2307/3150783.

Arregle, J.-L., Hitt, M. A., Sirmon, D. G., \& Very, P. (2007). The development of organizational social capital: Attributes of family firms. Journal of Management Studies, 44, 73-95. doi:10.1111/j.14676486.2007.00665.x .

Arregle, J.-L., Naldi, L., Nordqvist, M., \& Hitt, M. A. (2012). Internationalization of family-controlled firms: A study of the effects of external involvement in Governance. Entrepreneurship Theorya Practice, 36, 1115-1143. doi:10.1111/j.1540-6520.2012.00541.x .

Astrachan, J. H. (2003). Commentary on the special issue: The emergence of a field. Journal of Business Venturing, 18, 567-572. doi:10.1016/S0883-9026(03)00010-7 . 
Astrachan, J. H., Klein, S. B., \& Smyrnios, K. X. (2002). The F-PEC scale of family influence: A proposal for solving the family business definition problem. Family Business Review, 15, 45-58. doi:10.1111/j.17416248.2002.00045.x.

Atalay, M., Anafarta, N., \& Sarvan, F. (2013). The relationship between innovation and firm performance: An empirical evidence from Turkish automotive supplier industry. Procedia - Social and Behavioral Sciences, 75, 226-235. doi:10.1016/j.sbspro.2013.04.026 .

Bagozzi, R. P., \& Yi, Y. (1988). On the evaluation of structural equation models. Journal of the Academy of Marketing Science, 16, 74-94. doi:10.1007/BF02723327 .

Barney, J. (1991). Firm resources and sustained competitive advantage. Journal of Management, 17(1), 99120.

Basco, R. (2014). Exploring the influence of the family upon firm performance: Does strategic behaviour matter. International Small Business Journal, 32, 967-995. doi:10.1177/0266242613484946 .

Battisti, G., \& Stoneman, P. (2010). How innovative are UK firms?: Evidence from the fourth UK Community innovation survey on synergies between technological and organizational innovations. British Journal of Management, 21, 187-206. doi:10.1111/j.1467-8551.2009.00629.x .

Becker, W., \& Peters, J. (2000). Technological opportunities, absorptive capacities, and innovation. Volkswirtschaftliche Diskussionsreihe, Institut für Volkswirtschaftslehre der Universität Augsburg (No. 195). Augsburg.

Berrone, P., Cruz, C., \& Gómez-Mejía, L. R. (2012). Socioemotional wealth in family firms: Theoretical dimensions, assessment approaches, and agenda for future research. Family Business Review, 25, 258279. doi: $10.1177 / 0894486511435355$.

Birkinshaw, J., Hamel, G., \& Mol, M. J. (2008). Management innovation. Academy of Management Review, 33, 825-845. doi:10.5465/AMR.2008.34421969 .

Block, J. H. (2012). R\&D investments in family and founder firms: An agency perspective. Journal of Business Venturing, 27(2), 248-265.

Bouncken, R. B., Gast, J., Kraus, S., \& Bogers, M. (2015). Coopetition: A systematic review, synthesis, and future research directions. Review of Managerial Science, 9, 577-601. doi:10.1007/s11846-015-0168-6 .

Brush, C. G., \& Vanderwerf, P. A. (1992). A comparison of methods and sources for obtaining estimates of new venture performance. Journal of Business Venturing, 7, 157-170. doi:10.1016/0883-9026(92)90010-O .

Camisón, C., \& Villar-López, A. (2014). Organizational innovation as an enabler of technological innovation capabilities and firm performance. Journal of Business Research, 67, 2891-2902. doi:10.1016/j. jbusres.2012.06.004.

Chesbrough, H. W. (2006). Open innovation: The new imperative for creating and profiting from technology. Boston, Massachusetts: Harvard business press.

Chirico, F., \& Nordqvist, M. (2010). Dynamic capabilities and trans-generational value creation in family firms: The role of organizational culture. International Small Business Journal, 28, 487-504. doi:10.1177 /0266242610370402.

Chirico, F., \& Salvato, C. (2016). Knowledge internalization and product development in family firms: When relational and affective factors matter. Entrepreneurship Theory \& Practice, 40, 201-229. doi:10.1111 /etap.12114.

Chirico, F., Sirmon, D. G., Sciascia, S., \& Mazzola, P. (2011). Resource orchestration in family firms: Investigating how entrepreneurial orientation, generational involvement, and participative strategy affect performance. Strategic Entrepreneurship Journal, 5, 307-326. doi:10.1002/sej.121 .

Chrisman, J. J., Chua, J. H., De Massis, A., Frattini, F., \& Wright, M. (2015). The ability and willingness paradox in family firm innovation. Journal of Product Innovation Management, 32, 310-318. doi:10.1111/jpim.12207 .

Chrisman, J. J., Chua, J. H., \& Sharma, P. (2005). Trends and directions in the development of a strategic management theory of the family firm. Entrepreneurship Theory \& Practice, 29, 555-575. doi:10.1111 j.1540-6520.2005.00098.x .

Chrisman, J. J., \& Patel, P. C. (2012). Variations in R\&D Investments of Family and Nonfamily Firms: Behavioral agency and myopic loss aversion perspectives. Academy of Management Journal, 55, 976997. doi:10.5465/amj.2011.0211.

Chua, J. H., Chrisman, J. J., \& Sharma, P. (1999). Defining the family business by behavior. Entrepreneurship Theory \& Practice, 23(4), 19-39.

Classen, N., van Gils, A., Bammens, Y., \& Carree, M. (2012). Accessing resources from innovation partners: The search breadth of family SMEs. Journal of Small Business Management, 50, 191-215. doi:10.1111 jj.1540-627X.2012.00350.x . 
Covin, J. G., Eggers, F., Kraus, S., Cheng, C.-F., \& Chang, M.-L. (2016). Marketing-related resources and radical innovativeness in family and non-family firms: A configurational approach. Journal of Business Research, 69, 5620-5627. doi:10.1016/j.jbusres.2016.03.069 .

Damanpour, F. (2010). An integration of research findings of effects of firm size and market competition on product and process innovations. British Journal of Management, 21, 996-1010. doi:10.1111/j.14678551.2009.00628.x .

Damanpour, F., \& Aravind, D. (2012). Managerial innovation: Conceptions, processes and antecedents. Management and Organization Review, 8, 423-454. doi:10.1111/j.1740-8784.2011.00233.x .

Damanpour, F., \& Evan, W. M. (1984). Organizational innovation and performance: The problem of "organizational lag". Administrative Science Quarterly, 29, 392. doi:10.2307/2393031 .

Damanpour, F., \& Gopalakrishnan, S. (2001). The dynamics of the adoption of product and process innovations in organizations. Journal of Management Studies, 38, 45-65. doi:10.1111/14676486.00227 .

Damanpour, F., Walker, R. M., \& Avellaneda, C. N. (2009). Combinative effects of innovation types and organizational performance: A longitudinal study of service organizations. Journal of Management Studies, 46, 650-675. doi:10.1111/j.1467-6486.2008.00814.x .

De Massis, A., Frattini, F., \& Lichtenthaler, U. (2013). Research on technological innovation in family firms: Present debates and future directions. Family Business Review, 26, 10-31. doi:10.1177 /0894486512466258.

De Massis, A., Frattini, F., Pizzurno, E., \& Cassia, L. (2015). Product innovation in family versus nonfamily firms: An exploratory analysis. Journal of Small Business Management, 53, 1-36. doi:10.1111 /jsbm.12068.

Diéguez-Soto, J., Manzaneque, M., \& Rojo-Ramírez, A. A. (2016). Technological innovation inputs, outputs, and performance: The moderating role of family involvement in management. Family Business Review, 29, 327-346. doi:10.1177/0894486516646917.

Eckhardt, J. T., \& Shane, S. A. (2011). Industry changes in technology and complementary assets and the creation of high-growth firms. Journal of Business Venturing, 26, 412-430. doi:10.1016/j. jbusvent.2010.01.003.

Eddleston, K. A., Kellermanns, F. W., \& Sarathy, R. (2008). Resource configuration in family firms: Linking resources, strategic planning and technological opportunities to performance. Journal of Management Studies, 45, 26-50. doi:10.1111/j.1467-6486.2007.00717.x .

European Commission. (2003). Commission recommendations - concerning the definition of micro, small and medium-sized enterprises. Official Journal of the European Union, 124(36), 36-41.

Faems, D., van Looy, B., \& Debackere, K. (2005). Interorganizational collaboration and innovation: Toward a portfolio approach*. Journal of Product Innovation Management, 22, 238-250. doi:10.1111/j.07376782.2005.00120.x .

Fernandes, C. I., Ferreira, J. J., \& Raposo, M. L. (2013). Drivers to firm innovation and their effects on performance: An international comparison. International Entrepreneurship and Management Journal, 9 , 557-580. doi:10.1007/s11365-013-0263-6.

Field, A. P. (2013). Discovering statistics using IBM SPSS statistics (4th ed.). London: Sage.

Filser, M., Brem, A., Gast, J., Kraus, S., \& Calabrò, A. (2016). Innovation in family firms - examining the inventory and mapping the path. International Journal of Innovation Management. doi:10.1142 /S1363919616500547.

Fornell, C., \& Larcker, D. F. (1981). Evaluating structural equation models with unobservable variables and measurement error. Journal of Marketing Research, 18, 39-50. doi:10.2307/3151312 .

Garcés-Galdeano, L., Larraza-Kintana, M., García-Olaverri, C., \& Makri, M. (2014). Entrepreneurial orientation in family firms: The moderating role of technological intensity and performance. International Entrepreneurship and Management Journal, 1-19. doi:10.1007/s11365-014-0335-2 .

Grant, R. M. (1996a). Prospering in dynamically-competitive environments: Organizational capability as knowledge integration. Organization Science, 7, 375-387. doi:10.1287/orsc.7.4.375 .

Grant, R. M. (1996b). Toward a knowledge-based theory of the firm. Strategic Management Journal, 17, 109122. doi: $10.2307 / 2486994$.

Gronum, S., Verreynne, M.-L., \& Kastelle, T. (2012). The role of networks in small and medium-sized Enterprise innovation and firm performance. Journal of Small Business Management, 50, 257-282. doi:10.1111/j.1540-627X.2012.00353.x .

Gudmundson, D., Tower, C. B., \& Hartman, E. A. (2003). Innovation in small businesses: Culture and ownership structure do matter. Journal of Developmental Entrepreneurship, 8(1), 1-18.

Habbershon, T. G., \& Williams, M. L. (1999). A resource-based framework for assessing the strategic advantages of family firms. Family Business Review, 12, 1-25. doi:10.1111/j.1741-6248.1999.00001.x . 
Hair, J. F. (2006). Multivariate data analysis (6th ed.). Upper Saddle River, N.J., London: Prentice Hall PTR. Hayes, A. F. (2013). Introduction to mediation, moderation and conditional process analysis: A regressionbased approach. New York: Guilford Press.

Hoffmann, C., Wulf, T., \& Stubner, S. (2014). Understanding the performance consequences of family involvement in the top management team: The role of long-term orientation. International Small Business Journal. doi:10.1177/0266242614550500 .

Hollen, R. M., Van Den Bosch, F. A. J., \& Volberda, H. W. (2013). The role of management innovation in enabling technological process innovation: An inter-organizational perspective. European Management Review, 10, 35-50. doi:10.1111/emre.12003.

Hu, L., \& Bentler, P. M. (1999). Cutoff criteria for fit indexes in covariance structure analysis: Conventional criteria versus new alternatives. Structural Equation Modeling: A Multidisciplinary Journal, 6, 1-55. doi:10.1080/10705519909540118.

Innovationsindikator. (2015). Acatec/BDI Innovationsindikator 2015. http://www.innovationsindikator. de/fileadmin/2015/PDF/Innovationsindikator_2015_Web.pdf.

Jiménez-Jiménez, D., \& Sanz-Valle, R. (2011). Innovation, organizational learning, and performance. Journal of Business Research, 64, 408-417. doi:10.1016/j.jbusres.2010.09.010 .

Keh, H. T., Nguyen, T. T., \& Ng, H. P. (2007). The effects of entrepreneurial orientation and marketing information on the performance of SMEs. Journal of Business Venturing, 22, 592-611. doi:10.1016/j. jbusvent.2006.05.003 .

Kellermanns, F. W., Eddleston, K. A., Sarathy, R., \& Murphy, F. (2012). Innovativeness in family firms: A family influence perspective. Small Business Economics, 38, 85-101. doi:10.1007/s11187-010-9268-5 .

Khanagha, S., Volberda, H., Sidhu, J., \& Oshri, I. (2013). Management innovation and adoption of emerging technologies: The case of cloud computing. European Management Review, 10, 51-67. doi:10.1111 /emre.12004.

Klevorick, A. K., Levin, R. C., Nelson, R. R., \& Winter, S. G. (1995). On the sources and significance of interindustry differences in technological opportunities. Research Policy, 24, 185-205. doi:10.1016/00487333(93)00762-I .

Kogut, B., \& Zander, U. (1992). Knowledge of the firm, combinative capabilities, and the replication of technology. Organization Science, 3, 383-397. doi:10.1287/orsc.3.3.383 .

Kraus, S., Pohjola, M., \& Koponen, A. (2012a). Innovation in family firms: An empirical analysis linking organizational and managerial innovation to corporate success. Review of Managerial Science, 6, 265286. doi:10.1007/s11846-011-0065-6 .

Kraus, S., Rigtering, J. P. C., Hughes, M., \& Hosman, V. (2012b). Entrepreneurial orientation and the business performance of SMEs: A quantitative study from the Netherlands. Review of Managerial Science, 6, 161182. doi:10.1007/s11846-011-0062-9 .

Leal-Rodríguez, A. L., Albort-Morant, G., \& Martelo-Landroguez, S. (2016). Links between entrepreneurial culture, innovation, and performance: The moderating role of family firms. International Entrepreneurship and Management Journal. doi:10.1007/s11365-016-0426-3 .

Lee, J. (2006). Family firm performance: Further evidence. Family Business Review, 19, 103-114. doi:10.1111 j.1741-6248.2006.00060.x .

Lee, K. C., Lee, S., \& Kang, I. W. (2005). KMPI: Measuring knowledge management performance. Information Management, 42, 469-482. doi:10.1016/j.im.2004.02.003 .

Lindow, C. M., Stubner, S., \& Wulf, T. (2010). Strategic fit within family firms: The role of family influence and the effect on performance. Journal of Family Business Strategy, 1, 167-178. doi:10.1016/j. jfbs.2010.08.004 .

Llach, J., Marquès, P., Bikfalvi, A., Simon, A., \& Kraus, S. (2012). The innovativeness of family firms through the economic cycle. Journal of Family Business Management, 2, 96-109. doi:10.1108 /20436231211261853.

Lumpkin, G. T., \& Brigham, K. H. (2011). Long-term orientation and intertemporal choice in family firms. Entrepreneurship Theory \& Practice, 35, 1149-1169. doi:10.1111/j.1540-6520.2011.00495.x .

MacKinnon, D. P., Fairchild, A. J., \& Fritz, M. S. (2007). Mediation analysis. Annual Review of Psychology, 58, 593-614. doi:10.1146/annurev.psych.58.110405.085542 .

Maes, J., \& Sels, L. (2014). SMEs' radical product innovation: The role of internally and externally oriented knowledge capabilities. Journal of Small Business Management, 52, 141-163. doi:10.1111/jsbm.12037 .

Martínez-Ros, E., \& Labeaga, J. M. (2009). Product and process innovation: Persistence and complementarities. European Management Review, 6, 64-75. doi:10.1057/emr.2009.4 .

Matzler, K., Veider, V., Hautz, J., \& Stadler, C. (2014). The impact of family ownership, management, and Governance on innovation. Journal of Product Innovation Management, 32, 319-333. doi:10.1111 /jpim.12202 . 
Mazzanti, M., Pini, P., \& Tortia, E. (2006). Organizational innovations, human resources and firm performance. The Journal of Socio-Economics, 35, 123-141. doi:10.1016/j.socec.2005.12.007 .

Mol, M. J., \& Birkinshaw, J. (2009). The sources of management innovation: When firms introduce new management practices. Journal of Business Research, 62, 1269-1280 (2009). doi:10.1016/j. jbusres.2009.01.001.

Mol, M. J., \& Birkinshaw, J. (2012). Relating management innovation to product and process innovation: Private rents versus public gains. In T. S. Pitsis, A. Simpson, \& E. Dehlin (Eds.), Handbook of Orgainzational and managerial innovation (pp. 13-35). Cheltenham, UK, Northampton, MA, USA: Edward Elgar.

Molina-Morales, F. X., García-Villaverde, P. M., \& Parra-Requena, G. (2014). Geographical and cognitive proximity effects on innovation performance in SMEs: A way through knowledge acquisition. International Entrepreneurship and Management Journal, 10, 231-251. doi:10.1007/s11365-011-0214$\mathrm{z}$.

Naldi, L., Nordqvist, M., Sjöberg, K., \& Wiklund, J. (2007). Entrepreneurial orientation, risk taking, and performance in family firms. Family Business Review, 20, 33-47. doi:10.1111/j.1741-6248.2007.00082.x

Ngo, L. V., \& O’Cass, A. (2013). Innovation and business success: The mediating role of customer participation. Journal of Business Research, 66, 1134-1142. doi:10.1016/j.jbusres.2012.03.009 .

Nieto, M., \& Quevedo, P. (2005). Absorptive capacity, technological opportunity, knowledge spillovers, and innovative effort. Technovation, 25, 1141-1157. doi:10.1016/j.technovation.2004.05.001 .

Nieto, M. J., Santamaria, L., \& Fernandez, Z. (2015). Understanding the innovation behavior of family firms. Journal of Small Business Management, 53, 382-399 (2015). doi:10.1111/jsbm.12075 .

Nunnally, J. C. (1978). Psychometric theory (2nd ed.). New York: McGraw-Hill.

Ortega, M. J. (2010). Competitive strategies and firm performance: Technological capabilities' moderating roles. Journal of Business Research, 63, 1273-1281. doi:10.1016/j.jbusres.2009.09.007 .

Pett, T. L., \& Wolff, J. A. (2009). SME opportunity for growth or profit: What is the role of product and process improvement. International Journal of Entrepreneurial Venturing, 1, 5. doi:10.1504 /IJEV.2009.023817.

Preacher, K. J., \& Hayes, A. F. (2008). Asymptotic and resampling strategies for assessing and comparing indirect effects in multiple mediator models. Behavior Research Methods, 40, 879-891. doi:10.3758 /BRM.40.3.879 .

Preacher, K. J., Rucker, D. D., \& Hayes, A. F. (2007). Addressing moderated mediation hypotheses: Theory, methods, and prescriptions. Multivariate Behavioral Research, 42, 185-227. doi:10.1080 /00273170701341316.

Price, D. P., Stoica, M., \& Boncella, R. J. (2013). The relationship between innovation, knowledge, and performance in family and non-family firms: An analysis of SMEs. Journal of Innovation and Entrepreneurship, 2(1), 1-20.

Roessl, D., Fink, M., \& Kraus, S. (2010). Are family firms fit for innovation?: Towards an agenda for empirical research. International Journal of Entrepreneurial Venturing, 2, 366-380. doi:10.1504 /IJEV.2010.037118.

Russo, A., \& Vurro, C. (2010). Cross-boundary ambidexterity: Balancing exploration and exploitation in the fuel cell industry. European Management Review, 7, 30-45. doi:10.1057/emr.2010.2 .

Schulze, W. S., Lubatkin, M. H., Dino, R. N., \& Buchholtz, A. K. (2001). Agency relationships in family firms: Theory and evidence. Organization Science, 12, 99-116. doi:10.1287/orsc.12.2.99.10114 .

Sirmon, D. G., \& Hitt, M. A. (2003). Managing resources: Linking unique resources, management, and wealth creation in family firms. Entrepreneurship Theory \& Practice, 27, 339-358. doi:10.1111/1540-8520.t01$1-00013$.

Tabachnick, B. G., \& Fidell, L. S. (2012). Using Multivariate statistics (6th ed.). Boston: Pearson Education.

Teece, D. J., Pisano, G., \& Shuen, A. (1997). Dynamic capabilities and strategic management. Strategic Management Journal, 18(7), 509-533.

van de Vrande, V., de Jong, J. P., Vanhaverbeke, W., \& de Rochemont, M. (2009). Open innovation in SMEs: Trends, motives and management challenges. Technovation, 29, 423-437. doi:10.1016/j. technovation.2008.10.001 .

Vega-Jurado, J., Gutiérrez-Gracia, A., Fernández-de-Lucio, I., \& Manjarrés-Henríquez, L. (2008). The effect of external and internal factors on firms' product innovation. Research Policy, 37, 616-632. doi:10.1016 j.respol.2008.01.001 .

Volberda, H. W., Van Den Bosch, F. A. J., \& Heij, C. V. (2013). Management innovation: Management as fertile ground for innovation. European Management Review, 10, 1-15. doi:10.1111/emre.12007 . 
Voordeckers, W., van Gils, A., \& Van den Heuvel, J. (2007). Board composition in small and medium-sized family firms. Journal of Small Business Management, 45(1), 137-156.

Wales, W. J., Gupta, V. K., \& Mousa, F.-T. (2013). Empirical research on entrepreneurial orientation: An assessment and suggestions for future research. International Small Business Journal, 31, 357-383. doi:10.1177/0266242611418261.

Walker, R. M., Chen, J., \& Aravind, D. (2015). Management innovation and firm performance: An integration of research findings. European Management Journal, 33, 407-422. doi:10.1016/j.emj.2015.07.001 .

West, J., \& Bogers, M. (2014). Leveraging external sources of innovation: A review of research on open innovation. Journal of Product Innovation Management, 31, 814-831. doi:10.1111/jpim.12125 .

Xi, J., Kraus, S., Filser, M., \& Kellermanns, F. W. (2013). Mapping the field of family business research: Past trends and future directions. International Entrepreneurship and Management Journal, 11, 113-132. doi:10.1007/s11365-013-0286-z .

Zahra, S. A. (1996). Governance, ownership, and corporate Entrepreneurship: The moderating impact of industry technological opportunities. Academy of Management Journal, 39, 1713-1735. doi:10.2307 1257076 .

Zahra, S. A., \& Covin, J. G. (1994). The financial implications of fit between competitive strategy and innovation types and sources. The Journal of High Technology Management Research, 5, 183-211. doi:10.1016/1047-8310(94)90002-7 .

Zahra, S. A., Neubaum, D. O., \& Larrañeta, B. (2007). Knowledge sharing and technological capabilities: The moderating role of family involvement. Journal of Business Research, 60, 1070-1079. doi:10.1016/j. jbusres.2006.12.014.

Zellweger, T. M., Nason, R. S., \& Nordqvist, M. (2012). From longevity of firms to transgenerational Entrepreneurship of families: Introducing family entrepreneurial orientation. Family Business Review, 25, 136-155. doi:10.1177/0894486511423531.

Zhao, X., Lynch, J. G., \& Chen, Q. (2010). Reconsidering baron and Kenny: Myths and truths about mediation analysis. Journal of Consumer Research, 37, 197-206. doi:10.1086/651257 . 